\title{
First observations of ocellated lizard (Timon lepidus) in Gipuzkoa.
}

\section{Gardatxoaren (Timon lepidus) lehenengo behaketak Gipuzkoan.}

Ibai Ugarte-Zabaleta ${ }^{1,2 *}$, Iker Novoa ${ }^{1,3}$, Egoitz Alkorta ${ }^{4}$, Ander Izagirre ${ }^{4}$, Aitor Montes 5 Iñaki Sanz-Azkue 4

$$
\text { 6 }
$$

\section{Abstract}

The first four individuals of Timon lepidus (Daudin, 1802) have been observed in the province of Gipuzkoa where this species had not been recorded previously.

Key words: Oñati, Araotz, Basque Country, distribution.

\section{Laburpena}

Timon lepidus (Daudin, 1802) espezieko lau ale behatu dira Gipuzkoako probintzian, lehenengoak, aurretik espezie hau ez baitzegoen erregistratuta.

Gako hitzak: Oñati, Araotz, Euskal Autonomia Erkidegoa, banaketa.

\section{Resumen}

Se han observado los cuatro primeros individuos de lagarto ocelado Timon lepidus (Daudin, 1802) en la provincia de Gipuzkoa, donde anteriormente no estaba registrada la especie.

Palabras clave: Oñati, Araotz, País Vasco, distribución.

1 Oñatiko Naturzaliak. 20560 Oñati, Spain

2 Lope de Agirre kalea, 41 eskuina, 20560 Oñati, Spain

3 Kale zaharra, 542 D, 20560 Oñati, Spain

4 Aranzadi Science Society. Department of Herpetology. Zorroagaina 11. 20014 Donostia-S. Sebastian, Spain

5 Unzurrunzaga kalea, 71 A, 20214 Segura, Spain

*Corresponding author: eskolatxo@hotmail.com 
The ocellated lizard Timon Lepidus (Daudin, 1802) is endemic to the Iberian Peninsula, south of France and northwest of Italy. It is a characteristic species of regions subject to Mediterranean climate, where it prefers relatively open places with abundant shelter, such as pastures, rather than shrublands or dense forests (Mateo, 2002).

In the Basque Country, the first observation of this species took place in Laguardia, in the south of the province of Araba (Puente-Amestoy, 1956).Long after this, its presence was recorded in the regional survey, again in the south of Araba (Bea, 1985). Subsequently, the ocellated lizard was found in the most northern areas of the province (Domingo, 1995). The most up-to-date distribution, showing a number of observations in the west of Bizkaia and Araba provinces, is contained in SIARE (2017).

This record extends the distribution of the ocellated lizard in the Basque Country, sighting it for the first time in the province of Gipuzkoa. The first individual, a juvenile (Fig. 1a), was found by pure chance without following any type of methodology or being part of any research project, on 04.14.2017 at 12:38 in the neighbourhood of Araotz, southwest of Oñati (Lat: 43,007646; Long: -2,449604; 730 masl), within the Natural Park of Aizkorri-Aratz. The day was cloudy and without rain. It was sheltered under a limestone type rock, which was part of a small outcrop, surrounded by several species of shrubs and close to the small water reservoir of Aitzgaineko ur-biltegia (Lat: 43,0071; Long: -2,4511; UTM 30T WN44746176, 721 masl).

The observation area was dominated by grass, maintained by cattle, and shrubs mainly of Erica spp. accompanied by Rubus spp., Juniperus communis, Crataegus monogyna and Ulex spp. The climate of this area is temperate oceanic with a Mediterranean influence, which is reflected in the vegetation. Numerous outcrops of limestone rock rise from the floor, generating a karst-type geomorphology which predominates in the landscape of the observation area. The zone is located on a south-facing slope, which receives a greater amount of solar radiation. This may somewhat explain the presence of this thermophilic species.

After the discovery of the juvenile, in April 19, the same area was visited in order to find more specimens. None was seen at the same point, but it was possible to confirm the presence of the species in lower parts of the valley. Three more individuals were found: an immature male, an adult male (Fig. 1b) and a gravid female. All of them in meadows with a southern exposure, among 560-580 masl, (Lat=42,999951; Long=-2,446068). The first two were in a stone wall that separates the meadow from a scrub zone, and the third one was on a limestone outcrop near the edge of the meadow. The individuals were located in the afternoon in cloudy conditions, although the day had been quite warm until then. Due to the sighting over a period of a few days of at least 4 different specimens of ocellated lizard of different ages and genders, the existence of a consolidated population in this area of Gipuzkoa can be postulated. 

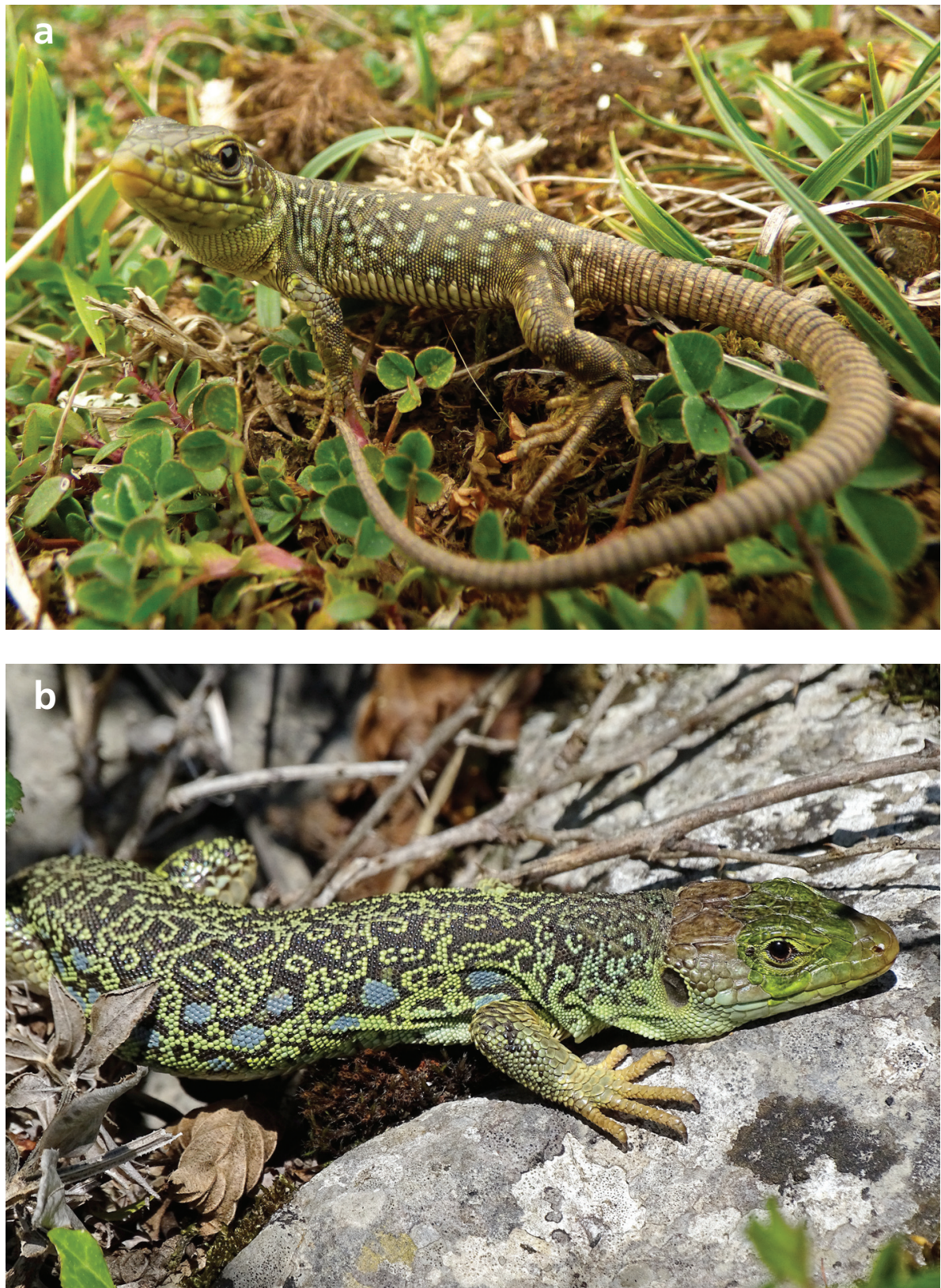

Fig. 1.- Specimens of Timon lepidus photographed in the Araotz Valley (province of Gipuzkoa). a. Juvenile. b. Adult male.

Fig. 1.- Individuos de Timon lepidus fotografiados en el valle de Araotz (provincia de Gipuzkoa). a. Juvenil. b. Macho adulto. 
In the sampled area the reptilian community is furthermore composed of: the Smooth snake Coronella austriaca Laurenti, 1768, Southern smooth snake Coronella girondica (Daudin, 1803), Aesculapian ratsnake Zamenis longissimus (Laurenti, 1768), Viperine snake Natrix maura (Linnaeus, 1758), Mediterranean grass snake Natrix astreptophora (López Seoane, 1884), Slow worm Anguis fragilis Linnaeus, 1758, Common wall lizard Podarcis muralis (Laurenti, 1768), Columbretes wall lizard Podarcis liolepis (Boulenger, 1905), Viviparous lizard Zootoca vivipara (Lichtenstein, 1823), Western green lizard Lacerta bilineata Daudin, 1802, Seoane's viper Vipera seoanei Lataste, 1879 and Schreiber's green lizard Lacerta schreiberi Bedriaga, 1878. As one might deduce, in the area there are species of thermophilic environments such as the ocellated lizard and species of cooler environments as the viviparous lizard. This shows the potential herpetological value of the Araotz Valley.

The three species of lizard can be found in sympatry even in the same wall, which creates a unique opportunity to study the potential ecological interactions among these species. This situation, although with less complexity, has also been observed in other similar sites as in Zigoitia (Araba), where specimens of ocellated lizard and western green lizard have been found in close proximity (Gosá \& Garin-Barrio, 2016). In addition to the afore-mentioned site of Zigoitia, there are other sites located at the same latitude that host these lizard species, such as Sierra de Aralar in Navarre (Gosá \& Bergerandi, 1994), which has similar habitats and environments. This may indicate that the colonization of this species in Gipuzkoa can be carried out from different areas influenced by Mediterranean climate, and also favoured by a global warming scenario which suggests that our observations might be the outcome of an ongoing northward expansion of the ocellated lizard distributional range.

\section{Bibliography}

Bea, A. 1985. Atlas de los anfibios y reptiles de Álava, Vizcaya y Guipúzcoa. En: Atlas de los vertebrados continentales de Álava, Vizcaya y Guipúzcoa (excepto Chiroptera). J. Álvarez, A. Bea, J.M. Faus, Í. Mendiola, E. Castién. Gobierno Vasco. Bilbao.

Domingo, M.A. 1995. Nuevos datos sobre la distribución del lagarto ocelado Lacerta lepida (Daudin, 1802) en la provincia de Álava (País Vasco). Munibe, Cienc. nat. 47: 111-112.

Gosá, A., Bergerandi, A. 1994. Atlas de distribución de los anfibios y reptiles de Navarra. Munibe. 46: 109-189.

Gosá, A., Garin-Barrio, I. 2016. Inventario herpetológico en el término municipal de Zigoitia (Álava). Memoria final (2013-2016). Ayuntamiento de Zigoitia-Gobierno Vasco.

Mateo, J.A. 2002. Lacerta lepida. En: Atlas y Libro Rojo de los Anfibios y Reptiles de España. J.M. Pleguezuelos, R. Márquez, M. Lizana (2ª impresión): 225-227. Dirección General de Conservación de la Naturaleza-Asociación Herpetológica Española. Madrid. 
Puente-Amestoy, F. 1956. Herpetología alavesa. Introducción a su estudio. Grupo de Ciencias Naturales Aranzadi - Real Sociedad Vascongada de Amigos del País: 3-17.

SIARE, 2017. Consultation on the distribution of Timon lepidus. Available from: http://siare.herpetologica.es/bdh/distribucion (Accessed: 09.21.2017). 